\title{
ALEKSEI N LEONTIEV'S RESEARCH ON MEMORY AND ITS MEANING AS THE SOVIET AVANT-GARDE SCIENCE OF THE FUTURE
}

\author{
A PESQUISA DE ALEKSEI N. LEONTIEV SOBRE A MEMÓRIA E SEU \\ SIGNIFICADO COMO CIÊNCIA SOVIÉTICA \\ DE VANGUARDA DO FUTURO
}

Anton Yasnitsky ${ }^{1, *}$

\begin{abstract}
This paper presents a notable Soviet psychologist of the Vygotsky-Luria Circle, Aleksei N. Leontiev, overviews his contribution to psychological research, and explores the Vygotsky-Leontiev-Zinchenko strand in psychological studies of human memory and remembering. The general framework of Vygotskian "Superman science" as a component of the unique Soviet avant-garde science is also covered in this paper.
\end{abstract}

Keywords: Lev Vygotsky. Ivan Pavlov. Aleksei N. Leontiev. Memory. Remembering.

RESUMO: Este artigo apresenta um reconhecido psicólogo soviético do Círculo VigotskiLuria, Aleksei N. Leontiev, traz uma visão geral de suas contribuições para a pesquisa em psicologia e explora a vertente Vigotski-Leontiev-Zinchenko dos estudos psicológicos sobre a memória humana e a recordação. O quadro geral da "ciência do super-homem" vigotskiana como componente da singular ciência soviética de vanguarda também é abordado neste artigo.

Palavras-chave: Lev Vigotski. Ivan Pavlov. Aleksei N. Leontiev. Memória. Recordação.

1.Unaffiliated researcher - Toronto, Canada.

*Correspondence author: anton.yasnitsky@gmail.com

This article draws a point of view that can be better understood in the body of the author's work. For this, we refer to some of his texts, which can be found at http://individual.utoronto.ca/yasnitsky/

Dossier organized by: Gisele Toassa and Ana Luiza Bustamante Smolka 


\section{Aleksei N. Leontiev: Three Reasons to Remember the Name}

Aleksei N. Leontiev (1903-1979) was a Soviet psychologist, whose life and legacy are closely associated with the names and scholarly legacies of prominent Soviet intellectuals: neuropsychologist Alexander Luria (1902-1977) and developmental psychologist Lev Vygotsky (1896-1934). The latter is well-known as the third member of the "troika" (the three, or threesome, in Russian) of Russian intellectuals on the list of "the 100 most eminent psychologists of the 20th century" (occupying the 83rd position and following his contemporaries Ivan Pavlov [1849-1936], on the 24th place, and Alexander Luria, on the 69th place on the list), as measured by a study conducted by and among North American scholars in early 21st century (HAGGBLOOM et al., 2002). It is by virtue of this association with the most eminent Russian psychologists (which is the first reason to remember his name) that Leontiev is known today-but definitely not only for that.

The second reason for Leontiev's historical fame, primarily in the domestic context, is his prominence in the history of Russian psychology of the Soviet era as a major administrative and organizational force, in his capacity as founder and first dean of one of the two national Institutes of Psychology_both officially sanctioned in December 1965 and launched in 1966 in the Soviet Union. Due to a combination of factors-such as personal charm, charisma, fluency in French (which suggested a somewhat aristocratic flavor so admired at that time in certain circles of Russian intelligentsia), and the notorious obscurity of his oral and written presentations (which created an enigmatic image and hinted at the possession of the mysterious supreme knowledge of a sage)-, Leontiev became a cult figure for his numerous admirers and followers in the Lomonosov Moscow State University (MSU), institution that would become a stronghold for the Leontievian clan until the very last days of his life.

Virtually immediately following his death, in 1979, the Leontievian reign at the MSU was overturned and overtaken by a rival clan of Soviet psychologists from the second most powerful Institute of Psychology, the one at the Leningrad (renamed St.-Petersburg) State University-the other institute that opened in 1966. The mastermind of this administrative coup was Boris Lomov (1927-1989) - a figure with higher-stakes connections than Leontiev's in the highest bodies of the Communist Party regime in the Soviet Union-and his numerous associates and members of his patron-client network. This power overtake triggered a "game of thrones" of local scale and, after a while, the remnants of the Leontievian clan eventually regained power at the Institute of Psychology in Moscow State University in $2000^{1}$. Thus, this university remains, perhaps, the only Russian stronghold of his former students and a key location of the cult of Aleksei N. Leontiev in the 21st century, but the charms of both the cult and the legacy of its main figure considerably decreased during this millennium.

Furthermore, there is a third reason why the image of Aleksei N. Leontiev has not faded away into complete posthumous oblivion, like many intellectuals before or after him: his Marxist-or quasiMarxist, as some might say-theorizing and speculations in the field of psychology and allied fields of knowledge. This aspect of his intellectual legacy brings us into the pre-history of what is now known as "cultural-historical psychology" and "activity theory" in the Soviet Union, as they were developed by the members of the so-called Vygotsky-Luria Circle (YASNITSKY, 2016b) ${ }^{2}$.

Historically, three names are often associated with the Circle: Vygotsky, Luria, and Leontiev. The three are often described as a "troika", which exclusively created the "cultural-historical theory" in the Soviet Union before World War II. Such a portrayal is definitely erroneous and does not fit the evidence that we now have. First, the label of "cultural-historical" emerged in the critical discussions 
of Vygotsky's and Luria's scholarship in the early 1930s, to be subsequently assimilated by Vygotsky's followers and broader academic community after Vygotsky's death (KEILER, 2019). Second, no such theory was ever created by Vygotsky, Luria or any of their associates: only a few-often inconsistent and self-contradictory theoretical sketches-of the psychological system of thought were produced. These sketches might cumulatively qualify for a claim for several theories in psychology, but definitely not a single finalized one. Third, the unity of the three key protagonists of the "troika" narrative kept relatively united for a short period of time, roughly between 1926 and 1930, to be gradually driven apart for several reasons in the 1930s. Finally, their roles within the Circle differed very much.

Luria was Vygotsky's long-time partner and collaborator: the duo had a considerable history of interrelations and productively, and worked on a number of studies and writing projects. Furthermore, despite Luria's numerous claims on several occasions, he was not only Vygotsky's humble follower and student, but was also instrumental in essentially influencing Vygotsky's thought and theorizing in many ways (LAMDAN, 2019). In contrast, Leontiev always played "second fiddle" in the work of this duo, although he also importantly contributed to the work of the Circle during the reductionist and mechanicist period of the so-called "instrumental psychology". And yet, Leontiev may be adequately understood as arguably Vygotsky's best student ever.

Vygotsky's distinct and uniquely idiosyncratic project in human sciences, as it was presented on numerous occasions in his oral reports, private writings, and published works throughout the last decade of his life, was the quest for a "new psychology" that he also formulated as a "science of Superman" or a "peak psychology" - that aimed (a) at the heights (as opposed to Freudian "depth" or "surface-level" of everyday behaviors of interest to behaviorists of various kinds) of the (b) potential supreme human being (as opposed to the actual existing average human type). This aspect of the core of Vygotsky's unique proposal as a perfect instance of the bold and radical "revolutionary experiments" in human sciences-such as the scientific quest for life extension and even immortality (KREMENTSOV, 2013) - and distinctly Soviet "avant-garde science" ${ }^{3}$ in psychological research has largely remained ignored and was brought to light most recently (YASNITSKY, 2019).

On a methodological and conceptual plane, there is another important proposal of Lev Vygotsky. He called for a "psychological materialism", for which he advocated by making an analogy with Karl Marx' and Friedrich Engels' "historical materialism”, as a methodological and conceptual framework between philosophy proper and concrete historical and sociological research. Similarly, Vygotsky's proposal for a "psychological materialism" reflected the perceived need for a middle-level knowledge basis between Marxist philosophy and concrete psychological research-theoretical and empirical alike-in the real-world context and the applied settings of the Soviet Union of the 1920s to the 1930s.

Vygotsky proposed writing a book on "psychological materialism", but never wrote such a book. In fact, in retrospect, neither of Vygotsky's two major proposals-the truly scientific "new psychology" of the Superman and the "psychological materialism" - was ever materialized during his lifetime. Yet, the last phrase of Vygotsky's obituary, that Leontiev published in 1934, unambiguously states: "What L. S. Vygotsky has done in science will not die, since it constitutes the first stage of the movement toward the truly scientific, Marxist psychology" (LEONTIEV, 1934). Thus, Leontiev may well be considered Vygotsky's best student due to being the only scholar of the time who made an effort for the theoretical development of Vygotsky's general and overarching Marxist psychological theory. Nevertheless, the material outcome of this effort-manuscripts and publications-did not appear until after Vygotsky's death. 


\section{A Brief Overview of Aleksei N. Leontiev's Publications}

During his lifetime, Leontiev made quite a few publications: the most updated list of his published scholarly works comprises 282 items apart from other, non-academic newspaper and journal publications, interviews, popular articles, etc. (the bibliography is available online at http://www.anleontiev.smysl.ru/sp_publ.htm). It appears that Leontiev did not produce very many books.

Table 1. Aleksei N Leontiev's monographs and major books.

\begin{tabular}{|c|c|c|c|c|c|}
\hline $\begin{array}{l}\text { Book title } \\
\text { in English }\end{array}$ & $\begin{array}{l}\text { Book title } \\
\text { in Russian }\end{array}$ & Publisher & $\begin{array}{c}\text { Year } \\
\text { of first } \\
\text { publication }\end{array}$ & Pages & Genre \\
\hline $\begin{array}{c}\text { Memory } \\
\text { Development }\end{array}$ & $\begin{array}{l}\text { Razvitie pamiati. } \\
\text { Eksperimental'noe } \\
\text { razvitie vysshikh } \\
\text { psikhologicheskikh } \\
\text { funktsii } \\
\end{array}$ & Uchpedgiz & 1931 & 280 & Monograph \\
\hline $\begin{array}{c}\text { Rehabilitation } \\
\text { of Hand Function }\end{array}$ & $\begin{array}{c}\text { Vosstanovlenie } \\
\text { dvizheniia. Issledovanie } \\
\text { vosstanovleniia funktsii } \\
\text { ruki posle raneniia }\end{array}$ & Sovetskaia nauka & 1945 & 231 & $\begin{array}{c}\text { Monograph } \\
\text { (in collaboration } \\
\text { with A V } \\
\text { Zaporozhets) }\end{array}$ \\
\hline $\begin{array}{c}\text { Outline of the } \\
\text { Psyche Development }\end{array}$ & $\begin{array}{l}\text { Ocherk } \\
\text { razvitiia psikhiki }\end{array}$ & $\begin{array}{l}\text { Voennyi pedagogicheskii } \\
\text { institut Sovetskoi Armii }\end{array}$ & 1947 & 120 & $\begin{array}{l}\text { Monograph/ } \\
\text { Brochure }\end{array}$ \\
\hline $\begin{array}{l}\text { The Problems of } \\
\text { Psyche Development }\end{array}$ & $\begin{array}{c}\text { Problemy } \\
\text { razvitiia psikhiki }\end{array}$ & $\begin{array}{l}\text { APN RSFSR (1st ed.); } \\
\text { Mysl' (2nd ed.); } \\
\text { Izdatel'stvo Moskovskogo } \\
\text { Universiteta } \\
\text { (3rd \& 4th ed.) }\end{array}$ & 1959 & 496 & $\begin{array}{l}\text { Collected } \\
\text { papers }\end{array}$ \\
\hline $\begin{array}{l}\text { Activity. } \\
\text { Consciousness. } \\
\text { Personality }\end{array}$ & $\begin{array}{l}\text { Deiatel'nost'. } \\
\text { Soznanie. } \\
\text { Lichnost' }\end{array}$ & Politizdat & 1975 & 304 & $\begin{array}{l}\text { Collected } \\
\text { papers }\end{array}$ \\
\hline
\end{tabular}

Curiously enough, only three items on the list may qualify as the author's major monographs, that is, books that Leontiev wrote fully (or relatively) independently as single purpose specialized projects. Even so, one of the three-the Rehabilitation of Hand Function, from 1945 (item 29 on the list) - was co-authored with his former student Aleksandr Zaporozhets (1905-1981). Another book is a 120 page-long extended brochure, titled the Outline of the Psyche Development [Ocherk razvitiia psikhiki], from 1947 (item 39 on the list), a shortened version of Leontiev's doctoral dissertation, written under the supervision of Ivan Pavlov's administrative and "intellectual heir", physiologist and academician Leon Orbeli (1882-1958), and defended in Leningrad in 1940 (the manuscript was lost during the World War II). The rest is scholarly articles, encyclopedia entries, brochures, edited books, and book compilations of the author's previously published texts, such as the two well-known books The Problems of Psyche Development [Problemy razvitiia psikhiki] (whose first edition dates from 1959) and Activity. Consciousness. Personality [Deiatel'nost'. Soznanie. Lichnost'] (whose first edition dates from 1975) - the book that was published in two editions within just four years before the author's death and is often positioned and discussed as Leontiev's 
major theoretical work, that summarized all his intellectual legacy up to the end of his life. However, one needs to keep in mind that Activity. Consciousness. Personality (1975; 2nd ed. 1977) was not a whole new and original monograph, but a collection of journal articles that he had published on different occasions, from 1947 to 1974.

Table 2. A N Leontiev's activity. Consciousness. Personality (1975):

The composition of the book and chronology of its chapters' first publications.

\begin{tabular}{|c|c|c|c|c|}
\hline \multirow{2}{*}{$\begin{array}{l}\text { Chapter } \\
\text { number }\end{array}$} & \multirow{2}{*}{ Chapter title } & \multirow{2}{*}{ Original title } & \multicolumn{2}{|l|}{ First publication } \\
\hline & & & Source & Year \\
\hline I & $\begin{array}{c}\text { Marksizm i } \\
\text { psikhologicheskaia nauka }\end{array}$ & $\begin{array}{c}\text { Karl Marks i } \\
\text { psikhologicheskaia nauka }\end{array}$ & $\begin{array}{l}\text { Voprosy pilkhologii, } \\
\text { no. } 5 \text {, p. } 3-16\end{array}$ & 1968 \\
\hline II & $\begin{array}{l}\text { Psikhicheskoe } \\
\text { otrazhenie }\end{array}$ & $\begin{array}{l}\text { Chuvstvennyi obraz i model' } \\
\text { v svete leninskoi teorii otrazheniia }\end{array}$ & $\begin{array}{l}\text { Voprosy pilkhologii, } \\
\text { no. } 2 \text {, p. } 34-45\end{array}$ & 1970 \\
\hline III & $\begin{array}{l}\text { Problema deiatel'nosti } \\
\text { v psikhologii }\end{array}$ & $\begin{array}{l}\text { Problema deiatel'nosti } \\
\text { v psikhologii }\end{array}$ & $\begin{array}{l}\text { Voprosy filosofii, } \\
\text { no. } 9, \text { p. } 95-108\end{array}$ & 1972 \\
\hline IV & $\begin{array}{l}\text { Deiatel'nost' } \\
\text { i soznanie }\end{array}$ & $\begin{array}{l}\text { Deiatel'nost' } \\
\text { i soznanie }\end{array}$ & $\begin{array}{l}\text { Voprosy filosofii, } \\
\text { no. } 12 \text {, p. } 129-140\end{array}$ & 1972 \\
\hline $\mathrm{V}$ & $\begin{array}{l}\text { Deiatel'nost' } \\
\text { i lichnost' }\end{array}$ & $\begin{array}{l}\text { Deiatel'nost' } \\
\text { i lichnost' }\end{array}$ & $\begin{array}{l}\text { Voprosy filosofii, } \\
\text { no. } 4 \text {, p. } 87-97 \text {; } \\
\text { no. } 5 \text {, p. } 65-78\end{array}$ & 1974 \\
\hline Appendix & Prilozhenie & $\begin{array}{l}\text { Psikhologicheskie voprosy } \\
\text { soznatel'nosti ucheniia }\end{array}$ & $\begin{array}{c}\text { Problemy psikhologii } \\
\text { ponimaniia. Izvestiia APN } \\
\text { RSFSR, vyp. } 7 \text {; p. } 3-40\end{array}$ & 1947 \\
\hline
\end{tabular}

The other major collection of Leontiev's work is his The Problems of Psyche Development (1959), which, in the Soviet Union alone (i.e. not to mention its foreign translations), was eventually reprinted in 4 editions overall (editions 2 to 4 in 1965, 1972, and 1981, respectively), and earned its author the prestigious Lenin Prize in 1963. In many ways reminiscent of Actvity. Consciousness. Personality due to its design, this book is, nevertheless, quite remarkable. The book's opening chapter, entitled "The problem of the emergence of sensation" [Problema vozniknoveniia oshchushcheniia], comprising a quarter of the whole book, was a first publication of a fragment of Leontiev's doctoral dissertation. This fragment not only sheds light on his and his team's research activities in Kharkov and Moscow, from 1933 to 1936, but also gives us an insight into an exciting development of quintessentially Vygotskian "avant-garde science" research program, that has been largely ignored and by-passed by the international scholarly community to date.

All this explains our subjective interest in and the objective importance of Leontiev's first book, Development of Memory, from 1931, written exclusively in the spirit of Vygotsky's "instrumental psychology" of the 1920s.

\section{Razvitie Pamiati: The Landmark of Vygotsky's Mechanistic "Instrumental Psychology"}

Apart from being Leontiev's first major book, the research behind Development of Memory, from 1931, is of considerable interest, because it truly stands out as the only major published work that ever came 
out as a solid—theoretically and empirically grounded-monument and, in a sense, manifesto of Vygotsky's "instrumental" research program during his reductionist and mechanicist period of the 1920s. Indeed, despite the publication of a series of other works under the name of either Vygotsky or Luria or both, none qualifies as genuinely innovative or original contributions to the "new psychology" advocated by Vygotsky. These publications were either teaching materials for poorly trained (i. e., lacking proper gymnasium education) undergraduate students from the democratic masses of the post-revolutionary time (such as Paedology of the school age, from 1928, or Paedology of the adolescent, published in three volumes, between 1929 and 1931), or popular scientific works for general readers (such as Ape, Primitive Man, and Child: Essays in the History of Behaviour or Imagination and Creativity in Childhood, both from 1930). In fact, these volumes from 1930 to 1931-along with the considerably delayed Psychological Dictionary, from 1931, that Vygotsky co-authored with his younger associate Boris Varshava (1900-1927) — were the last books with Vygotsky's name on their cover that their author saw published ${ }^{4}$. Besides these works, there was the bulk of Luria's independent research projects done in parallel with his involvement in Vygotsky's research and quite distant from his scientific agenda. An example of the latter is Luria's well-known and influential book The Nature of Human Conflicts, which was published in English, in the United States, in 1932.

In contrast, Leontiev's Razvitie pamiati [Development of Memory] (LEONTIEV, 1931) presented considerable data and theoretical generalizations that were done within Vygotsky's research program and fully reflect the state of the art in emerging Vygotsky's theory by late 1929 (the composition of the book was formally finished roughly by 1930, but delayed in printing and publication). The book is a perfect expression of Vygotsky's theorizing and research program of the 1920s in the naïve and simplistic beauty of early Vygotskian "instrumentalism”.

The main idea is the development of a mastery of the subject's own behavior and performance: in this particular study, this meant the mastery of the psychological processes of memory and attention in its subjects. In the manner characteristic of this period of thought, the researchers, as designers of the study, never questioned the subjects' interest or eagerness to master their psychological performance, as it was-quite unfortunately-assumed as self-evident. Then, from the theoretical standpoint, the researchers postulated that two types of psychological functions existed: the "lower", "natural" ones and the "higher" "cultural" functions. These theorists never bothered to clearly define what these "lower" psychological functions were and what exactly would distinguish them from purely physiological processes. Instead, though, they articulated what they saw as the main difference between the undefined "lower" and the advanced "higher" functions. The distinction was the origin of the latter: the "higher" functions were believed to emerge as a result of instrumental use of some "cultural tools", artificially created by humankind in the cultural development process of the human species. Then, from this rather general assumption about the history of cultural development of Homo sapiens, the researchers made quite a dramatic leap to ontogenesis (i. e., individual development of children, who, in fact, were the most important group of participants in the study).

In order to demonstrate the correctness of their theoretical claims and assumptions, the researchers presented their subjects with what they thought to be totally meaningless "cultural tools", the "signs" that would help the participants of the experiment to master their psychological processes of remembering and attention, by virtue of association of these signs with the objects to be remembered or to be attended to. The specific experimental procedures and the main findings of this study are well-known and were generously described and discussed elsewhere. The discussion of the method of "double simulation" (YASNITSKY, 2018, p. 37-40), Vygotskian "instrumental psychology" (YASNITSKY, 2018, p. 65-69) and the "unexpected discoveries" of word meaning, dialogue, and inner speech (YASNITSKY, 2018, p. 69-73) can be found in Yasnitsky's most recent book, Vygotsky: An Intellectual Biography (YASNITSKY, 2018). According to the book review, it brought its 
author the flattering reputation of the "new world leader in doing careful analytic work on Vygotsky's heritage" Suffice it to say that, in his first book, from 1931, Leontiev triumphantly reported the empirically achieved demonstration, in experimental settings, of such processes. Thus, he was able to defend the discovery of what they believed to be the development of "cultural psychological functions" of logical memory and voluntary attention with the help of "mediation" of meaningless signs as "cultural tools". That explains why, in this book, these "higher functions" were also referred to as "mediated functions.'

\section{Leontiev's Revisionism as an Avant-Garde Science Project}

However, the triumph almost immediately turned into a disaster. Due to a combination of personal and social factors, the researchers of the Vygotsky-Luria Circle very soon (and even before the publication of the book) realized numerous, almost fatal problems with their theoretical assumptions, the study design, and the analytic procedures, as well as with key findings and interpretations. The first attempt to somehow rectify the situation was made in the very introduction to Leontiev's book: the introduction was authored by Vygotsky. Apparently, that was not enough. Then, this was followed by another text, published separately as a small brochure and signed by the names of Vygotsky and Leontiev-their only co-authored publication. This brochure came out in 1932 and was distributed along with the book as its appendix with even further clarifications, self-criticisms, and more philosophically grounded attempts at correcting theoretical flaws of the book (VYGOTSKII; LEONTIEV, 1932). A remark is in place: a Lusophone reader might be delighted to know that this text is being introduced, for the first time, as a translation into Portuguese in this very special issue of Cadernos CEDES.

These numerous flaws, though, could not be corrected other than in another experimental study, which would not be launched until Leontiev had established a major research center in Kharkiv ${ }^{6}$, at the time capital of Soviet Ukraine, to where he (along with Luria) relocated in 1931. There, Leontiev quickly recruited a new research team, which carefully investigated the pitfalls of Vygotskian "instrumentalism", and launched research under the supervision of Leontiev. Said research comprised three main strands: first, a revisionist study on memory, conducted primarily by Leontiev's student Piotr Zinchenko (1903-1969); second, a groundbreaking project on the origin of sensation that provided Leontiev with experimental data for his own doctoral study; and, third, after Leontiev's departure from Kharkiv, in 1934, a large-scale study on perception [vospriiatie], conducted by Leontiev's former student, administrative successor in Kharkiv and the future collaborator on Leontiev's second book, Aleksandr Zaporozhets. This major study by the Zaporozhets' team can be seen as the direct and enriched continuation of early Vygotsky's work on "psychology of art", and a contribution to the development of the "new man", or Superman, in Vygotsky's parlance. To our great regret, the final manuscript of Zaporozhets' doctoral dissertation perished during World War II, in a heavily bombed and largely destroyed Kharkiv, several times occupied and retaken by the Nazi and the Soviet Red Army forces. The detailed discussion of the Zaporozhets' team's research remains beyond the scope of this paper. Fortunately, these studies were sufficiently well presented and discussed in a series of publications on the so-called "Kharkov School of Psychology" (YASNITSKY; FERRARI, 2008a, 2008b).

Apparently, Aleksei N. Leontiev learned the lesson well from his experience with his first book and its multiple flaws. Indeed, Piotr Zinchenko's study, under the guidance of Leontiev, perfectly demonstrated clear understanding of the Vygotsky's "instrumentalism" main weaknesses, which Vygotsky most critically scrutinized in his "revisionist" writings, such as the aforementioned work (VYGOTSKII; LEONTIEV, 1932), as well as in his numerous private notes and public presentations of roughly 1930 to 1932 . Following the 
"revisionist Vygotsky" himself and a few of his contemporaries-such as the founder of Soviet Marxist psychology, Sergei Rubinstein (1889-1960) (YASNITSKY, 2020)—, Zinchenko generously and very correctly criticized the radical distinction between the "natural' lower and the "cultural" higher functions. Furthermore, he hinted at his familiarity with Vygotsky's self-criticism of isolated psychological functions in favor of a system of such functions: in his research, Zinchenko investigated not an isolated and fairly abstract "memoryfunction," as if such a "function" in fact existed. Moreover, he astutely avoided an implied bias of a unified "memory," as presumably a tripartite cognitive capacity for "information storage, preservation, and retrieval," derived from computer and cognitive sciences parlance that would come to prominence in psychology under the intellectual influence and domination of North American thought-style after WWII. Instead, Zinchenko focused on a concrete, real-world process of remembering. The design of his study was slightly reminiscent of the "instrumental method" of "double stimulation;" yet, instead of meaningless signs (as theoretical notions that help to explain the process of "mediation" and "internalization"), Zinchenko reconceptualized the "psychological tools" as having their objective meaning and subjective sense-the distinction and the interplay between the two (and the multiple derivatives of "sense" and "consciousness") are absolutely essential (YASNITSKY; VAN DER VEER, 2016a).

Zinchenko and his academic supervisor Leontiev demonstrated that remembering, as a live and dynamic psychological process in real world settings, is a function of concrete meaningful activity ${ }^{8}$ and operations with objects. Unlike Vygotsky's and early Leontiev studies on the artificial development of voluntary, logical memory, remembering, in Zinchenko-Leontiev's experiments was involuntary, but, by virtue of being a part of personally meaningful activity, in many instances by its efficiency, it would even surpass voluntary, yet mechanical memorization in the studies of Vygotsky. Moreover, Zinchenko-Leontiev drew the distinction between the object and the background of activity in a manner similar to the Gestaltist conceptual pair of figure and background ${ }^{9}$. They demonstrated that not only the object of meaningful activity is remembered involuntarily in agency, but also that even the background objects are remembered, too, although at a considerably lower rate. One might speculate that remembering background objects might be partly attributed to the subconscious, subjective, personal sense these objects have to people; but this is a theoretical proposal that does not seem to really ever occur to the originators of the study.

The exciting study by Zinchenko-Leontiev belongs to the classics of psychological research and, in many ways, predated later developments in Western psychology (CRAIK; LOCKHART, 2008; MACE, 2008; MCCAFFERTY, 2008; MESCHERYAKOV, 2008). Yet, the full beauty of Vygotsky's proposal of an "avantgarde science" of the Superman psychology unfolds in Leontiev's team's daring research on the emergence and development of sensation, which, by the standards of contemporary post-positivist science, might qualify as marginally "scientific" and bordering on parapsychology.

Indeed, in his doctoral research, Leontiev assumed that, in experimental settings, sensation can be developed-not only that which normally exists in human beings, but also sensations that are not observed under normal circumstances. In this case, Leontiev tested human ability in order to develop a sensation of light color by the skin of a human hand, which, by all standards of average, "normal" human behavior, should be regarded as an extra-sensory ability. In the rigorous experimental settings of psycho-physiological laboratories in Moscow and Kharkiv, Leontiev conducted his study under the supervision of Ivan Pavlov's closest student and intellectual heir, Leon Orbeli. Here, he was able to demonstrate the incredible: under certain circumstances, the subjects of his experiments were capable of developing extra-sensory abilities! The avant-garde spirit of Vygotskian over-optimistic research program reveals itself in the researchers' belief in the virtually endless plasticity of human nature, the extreme audacity of research goals, and the radicalism of the study, that would hardly be conceivable in any intellectual milieu other than that of the Soviet intellectual environment. 
Unfortunately, the magnitude and the full potential of this study remain unexplored until this very day. The study was concluded by 1940. Academician Leon Orbeli, the supervisor and official leading Soviet physiologist, approved this research. Sergei Rubinstein, the dissertation examiner, the first ever psychologist soon thereafter to become a corresponding member of the Academy of Sciences of the USSR and the official leading Soviet Marxist psychologist, approved it as well. Josef Stalin's Soviet Union and Adolf Hitler's Germany were still best friends. The Nazi invasion of the Soviet Union had not as yet started. Leontiev successfully defended his dissertation in the early years of WWII, at Orbeli's institute, in "the city of Lenin"-Leningrad. This was a true triumph of Vygotskian "Superman science," and the revolutionary avant-garde research of the unique Soviet style. And yet, despite a few humble attempts at continuation, after WWII, for instance, of the groundbreaking work of Aleksandr Zaporozhets and his associate, this line of radical, avant-garde experimentation was never fully resumed. To tell a story of this avant-garde scientific project would be a truly exciting undertaking.

Yet, this would be a whole new story of its own, beyond the scope of this paper.

\section{Acknowledgement}

The organizers of the dossier would like to thank Lucia Reily for the technical revision of the text in English and for its translation into Portuguese.

\section{Notes}

1. On the clans of Soviet psychologists and their "games of thrones", the idiosyncratic ethos of Soviet and contemporary Russian psychologists, the "Stalin model of science" and the "archetype of Soviet psychology", see Yasnitsky (2016a), also available in Spanish as the first chapter in Yasnitsky et al. (2016).

2. This text is also available in Spanish, as a book chapter in Yasnitsky et al. (2016).

3. An interesting example of the "avant-garde science" is the case of Russian scholar and expatriate philologist and linguist, Vygotsky's contemporary and Luria's associate, Roman Jakobson (1896-1982) (TOMAN, 1995).

4. For the most reliable academic bibliography of Vygotsky, see van der Veer and Yasnitsky (2016a). For a detailed overview of Vygotsky's publications, see also van der Veer and Yasnitsky (2016b), available as well in Spanish, as a book chapter in Yasnitsky et al. (2016).

5. From the book endorsement written by Jaan Valsiner (Aalborg University, Denmark) on the book cover (emphasis added): “This is the first thorough coverage of the life and work of this Russian-Jewish scholar since my work with René van der Veer over twenty-five years ago (Understanding Vygotsky, 1991). Vygotsky's psychological theories, based on his deep feelings on theatre and literature, continue to fascinate scholars worldwide. Yasnitsky has clearly emerged as the new world leader in doing careful analytic work on Vygotsky's heritage." Along these lines, the author's and his associates' somewhat earlier work (YASNITSKY; VAN DER VEER, 2016b) has received a high assessment from Brazilian scholar of Cuban origin Fernando Luis González-Rey: "This book both challenges myths and introduces new beginnings for a contemporary study of Vygotsky's classical works." For a much lengthier discussion of the topic by the same Cuban author, in Spanish, see Rey (2016).

6. Alias: Kharkov, in traditional Russian spelling of the city.

7. Piotr (Petr, or Peter; Petro in Ukrainian) Zinchenko (not to be confused with Vladimir Petrovich Zinchenko [1931-2014], his son, also a noted Soviet-then, Russian - psychologist) has remained a virtually unknown figure to a Lusophone reader. So, the longest and, perhaps, the best exposition of Zinchenko's work in Portuguese can be found in doctoral dissertation by Sandro Henrique Vieira De Almeida, entitled Psicologia Histórico-cultural da Memória, and defended in 2008 at Pontifícia Universidade Católica de São Paulo. At the time of writing this paper, the full text of the dissertation is available online: http://livros01.livrosgratis.com.br/cp056390.pdf. For the discussion of Zinchenko's study in question, see specifically pages 86 to 102 . For apparent reasons, the author of the present article does not have to agree with each and every statement made in this dissertation, yet highly recommends the text to the Lusophone readership. In addition, a couple of Zinchenko's studies and publications of 1930s are available in English translations (ZINCHENKO, 1983, 2008). 
The reader might also benefit from getting acquainted with discussion of Zinchenko's and Zinchenko-inspired researches, in its historical development, in Mescheryakov (2008), Yasnitsky (2008), and Yasnitsky and Ivanova (2011).

8. Expression "meaningful/cognized activity" [osmyslennaia deiatel'nost'] was overtaken by "object-related activity" [predmetnaia deiatel'nost'] in Leontiev's later, speculative quasi-Marxist works.

9. For the multiple interconnections between Soviet psychologists of the Vygotsky-Luria Circle and the German-American Gestalt psychologists, see Yasnitsky and van der Veer, $2016 \mathrm{~b}$.

\section{REFERENCES}

CRAIK, F.; LOCKHART, R. Levels of processing and Zinchenko's approach to memory research. Journal of Russian and East European Psychology, v. 46, n. 6, p. 52-60, 2008. https://doi.org/10.2753/ RPO1061-0405460605

GONZÁLEZ-REY, F. L. Prólogo. In: YASNITSKY, A. et al. (eds.). Vygotski revisitado: Una historia crítica de su contexto y legado. Buenos Aires: Miño y Dávila Editores, 2016, p. 17-35.

HAGGBLOOM, S. J. et al. The 100 most eminent psychologists of the 20th century. Review of General Psychology, v. 6, n. 2, p. 139-152, 2002. https://doi.org/10.1037//1089-2680.6.2.139

KEILER, P. A history of the social construction of the "cultural-historical". In: YASNITSKY, A. (ed.). Questioning Vygotsky's legacy: Scientific psychology or heroic cult. London/New York: Routledge, 2019, p. 91-130.

KREMENTSOV, N. Revolutionary experiments: The quest for immortality in Bolshevik science and fiction. Oxford: Oxford University Press, 2013.

LAMDAN, E. Vygotsky's "significant other": Alexander Luria's contribution to the development of Vygotsky's ideas. In: YASNITSKY, A. (ed.). Questioning Vygotsky's legacy: Scientific psychology or heroic cult. London/New York: Routledge, 2019, p. 65-90.

LEONTIEV, A. N. Razvitie pamiati. Eksperimental'noe issledovanie vysshikh psikhologicheskikh funktsii [Development of memory. Experimental research on higher psychological functions]. Moscow: Uchpedgiz, 1931.

LEONTIEV, A. N. Lev Semenovich Vygotskii. Sovetskaia psikhonevrologiia, n. 6, p. 188-190, 1934.

MACE, J. H. The involuntary/voluntary distinction: Implications for learning and memory and the contributions of P. I. Zinchenko. Journal of Russian and East European Psychology, v. 46, n. 6, p. 46-51, 2008. https://doi.org/10.2753/RPO1061-0405460604

MCCAFFERTY, S. G. Zinchenko's research on memory and pedagogical applications: Commentary on Meshcheryakov. Journal of Russian and East European Psychology, v. 46, n. 6, p. 41-45, 2008. https://doi.org/10.2753/RPO1061-0405460603

MESCHERYAKOV, B. G. The mnemic effects of P.I. Zinchenko. Journal of Russian and East European Psychology, v. 46, n. 6, p. 15-40, 2008. https://doi.org/10.2753/RPO1061-0405460602

TOMAN, J. The magic of a common language: Jakobson, Mathesius, Trubetzkoy, and the Prague Linguistic Circle. Cambridge: MIT Press, 1995. 
VAN DER VEER, R.; YASNITSKY, A. Vygotsky's published works: A(n almost) definitive bibliography. In: YASNITSKY, A.; VAN DER VEER, R. (eds.). Revisionist Revolution in Vygotsky Studies. London/ New York: Routledge, 2016a, p. 243-260.

VAN DER VEER, R.; YASNITSKY, A. Vygotsky the published: Who wrote Vygotsky and what Vygotsky actually wrote. In: YASNITSKY, A.; VAN DER VEER, R. (eds.). Revisionist Revolution in Vygotsky Studies. London/New York: Routledge, 2016b, p. 73-93.

VYGOTSKII, L. S.; LEONTIEV, A. N. Predislovie k knige A. N Leont'eva “Razvitie pamiati”. In: Prilozhenie k knige A. N Leont'eva “Razvitie pamiati”. Moscow, [s. n.], p. 2-11, 1932.

YASNITSKY, A. Piotr Zinchenko's psychology: A brief history of ideas. Journal of the Russian and East European Psychology, v. 46, n. 5, p. 3-7, 2008. https://doi.org/10.2753/RPO1061-0405460500

YASNITSKY, A. The archetype of Soviet psychology: From Stalinism of the 1930s to the "Stalinist science" of our days. In: YASNITSKY, A.; VAN DER VEER, R. (eds.). Revisionist Revolution in Vygotsky Studies. London/New York: Routledge, 2016a, p. 3-26.

YASNITSKY, A. Unity in diversity: Vygotsky-Luria Circle as an informal personal network of scholars. In: YASNITSKY, A.; VAN DER VEER, R. (eds.) Revisionist Revolution in Vygotsky Studies. London/ New York: Routledge, 2016b, p. 27-49.

YASNITSKY, A. Vygotsky: An intellectual biography. London/New York: Routledge, 2018.

YASNITSKY, A. Vygotsky's science of superman: From utopia to concrete psychology. In: YASNITSKY, A. (ed.). Questioning Vygotsky's legacy: Scientific psychology or heroic cult. London/New York: Routledge, 2019, p. 1-21.

YASNITSKY, A. Sergei Rubinstein the founder of Soviet Marxist psychology: "Problems of psychology in the works of Karl Marx" (1934) and beyond. In: YASNITSKY, A. (ed.). A history of Marxist psychology: The golden age of Soviet science. London/New York: Routledge, 2020.

YASNITSKY, A. et al. (ed.). Vygotski revisitado: Una historia crítica de su contexto y legado. Buenos Aires: Miño y Dávila Editores, 2016.

YASNITSKY, A.; VAN DER VEER, R. "Lost in translation": talking about sense, meaning, and consciousness. In: YASNITSKY, A.; VAN DER VEER, R. (Ed.) Revisionist Revolution in Vygotsky Studies. London \& New York: Routledge, 2016a. p. 229-239.

YASNITSKY, A.; VAN DER VEER, R. (Ed.) Revisionist Revolution in Vygotsky Studies. London \& New York: Routledge, 2016b.

YASNITSKY, A.; FERRARI, M. From Vygotsky to Vygotskian psychology: Introduction to the history of the Kharkov school. Journal of the History of the Behavioral Sciences, v. 44, n. 2, p. 119-145, 2008a. https://doi.org/10.1002/jhbs.20303

YASNITSKY, A.; FERRARI, M. Rethinking the early history of post-Vygotskian psychology: the case of the Kharkov school. History of Psychology, v. 11, n. 2, p. 101-121, 2008b. 
YASNITSKY, A.; IVANOVA, E. F. Rethinking the early history of post-Vygotskian psychology: The case of the Kharkov school. History of Psychology, v. 11, n. 2, p. 101-121, 2008b. https://doi. org/10.1037/1093-4510.11.2.101

YASNITSKY, A.; IVANOVA, E. F. Remembering for the future: Grigorii Sereda in the history of Kharkov school of psychology. Journal of Russian and East European Psychology, v. 49, n. 1, 2011. https://doi.org/10.2753/RPO1061-0405490100

ZINCHENKO, P. I. The problem of involuntary memory. Soviet psychology, v. 22, n. 2, p. 55-111, 1983. https://doi.org/10.2753/RPO1061-0405220255

ZINCHENKO, P. I. On forgetting and remembering school knowledge. Journal of Russian and East European Psychology, v. 46, n. 5, p. 8-42, 2008.

Received: 01 July 2019

Accepted: 30 Nov 2019

Cedes Editorial Committee/Coordination of this issue:

Silvia Cordeiro Nassif and Maria Silvia Pinto de Moura Librandi da Rocha 